\title{
Regioselective reduction of benzylidene acetals from a bis- heterocyclic pyrimidino-pyranoside platform
}

\author{
Issa Samb ${ }^{1, *}$ and Mohamed Lamine Gaye ${ }^{2}$ \\ ${ }^{1}$ Organic and Therapeutic Chemistry Research Team (ECOT), University Alioune Diop, de Bambey, \\ BP 30, Bambey, Senegal \\ ${ }^{2}$ Department of Chemistry, University Cheikh Anta DIOP, Dakar, Senegal
}

\begin{abstract}
After the preparation with few steps of the original bicyclic osidic scaffold of pyrimidino-pyranoside type, the exploration of the reactivity of the pyranose part allowed us to carry out different procedures for opening 4,6-O-benzylidene.
\end{abstract}

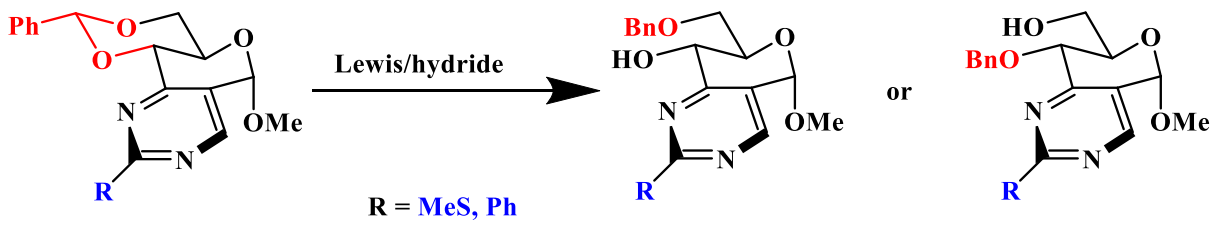

Figure 1. Regioselective reduction of benzylidene

This work reports regioselective reduction reactions of benzylidene acetals moieties which generate anchor points of new functions such as acetyls groups.

Keywords: Regioselective reduction, benzylidene acetals, peptidomimetics, bis-heterocyclic pyrimidinopyranoside

\section{Introduction}

The use of sugar as a rigid chiral platform that essential groups can functionalize was developed by Hirschmann in $1992^{1}$; thus preparing the first series of somatostatin1 receptor antagonist saccharide peptidomimetics.

This concept was taken up to develop a bicyclic ${ }^{2-4}$ osidic moiety, playing the role of a central body to prepare (Arg-Gly-Asp) RGD peptidomimetics.

The openings of benzylidene acetals moieties are often made by reducing reaction with a Lewis acid/hydride couple. The nature of the reducing / Lewis acid couple and that of the sugar considerably influence the regioselectivity of the reduction, i.e., the ratio $(6-\mathrm{OBn} / 4-\mathrm{OBn})^{5-9}$.

\section{Methodology}

2.1. Regioselective opening of the benzylidene of compound 1

Compound 1, resulting from the coupling between phenylboronic acid and SMe-pyrimidino-pyranoside, was chosen to study the reactivity of the sugar part of the platform, namely the regioselective opening of the benzylidene acetal by different hydride/Lewis acid pairs. As described for compound 1 in Scheme 1, the $\mathrm{Et}_{3} \mathrm{SiH} / \mathrm{BF}_{3} . \mathrm{OEt}_{2}$ couple made it possible to obtain compound 3 having a free hydroxyl in position 4 and a benzyl ether in position 6 with a modest yield of $47 \%$. However, we also note the presence of other products challenging to purify and unidentified. 

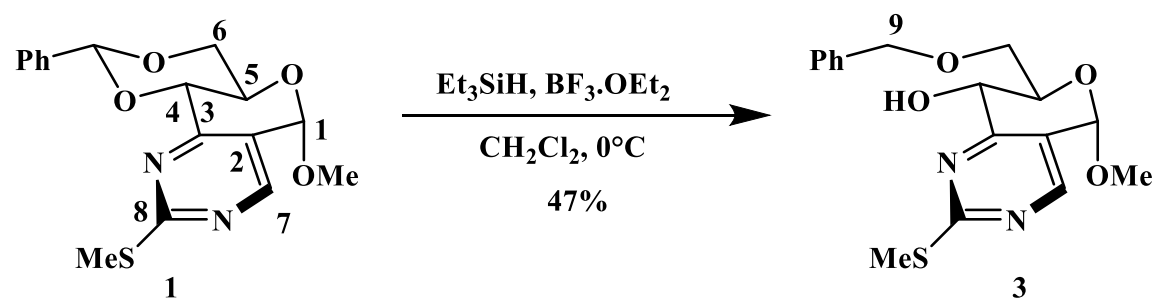

\section{Scheme 1.}

2.2. Regioselective opening of the benzylidene of compound 2

In this part, compound 2, resulting from the coupling between phenylboronic acid and Ph-pyrimidinopyranoside, was chosen instead of compound 1 .
The use of $\mathrm{Et}_{3} \mathrm{SiH} / \mathrm{BF}_{3} . \mathrm{OEt}_{2}$ and $\mathrm{LiAlH}_{4} / \mathrm{AlCl}_{3}$ pairs made it possible to obtain opening products having a benzyl ether in position 6 and a free alcohol function in position 4 with good yields of $86 \%$ and $65 \%$, respectively, Scheme 2.
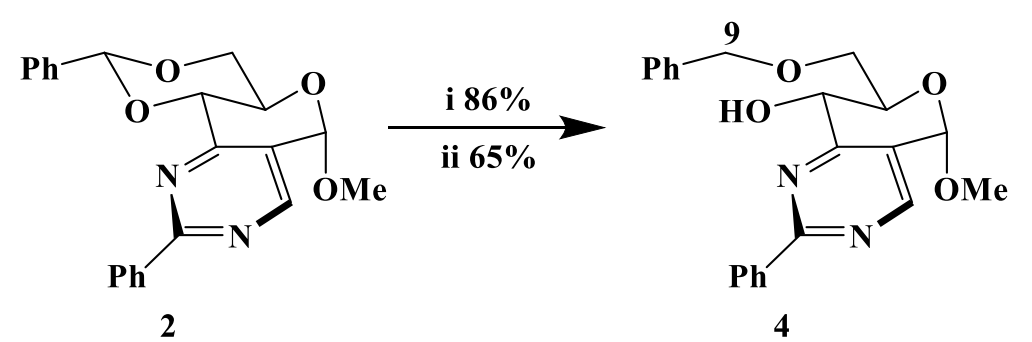

Scheme 2. i) $\mathrm{Et}_{3} \mathrm{SiH}, \mathrm{BF}_{3} . \mathrm{OEt}_{2}, \mathrm{CH}_{2} \mathrm{Cl}_{2}$ à $-78^{\circ} \mathrm{C}$, ii) $\mathrm{LiAlH}_{4} / \mathrm{AlCl}_{3}, \mathrm{Et}_{2} \mathrm{O}, \mathrm{CH}_{2} \mathrm{Cl}_{2}$

With the $\mathrm{Et}_{3} \mathrm{SiH} / \mathrm{PhBCl}_{2}$ pair, reverse regioselectivity was observed and led to the formation of compound 5 (6-OH and 4-OBn) with a yield of $72 \%$, Scheme 3.<smiles>COc1c2nc(-c3ccccc3)nc1C1COC(O2)c2ccccc21</smiles>
2

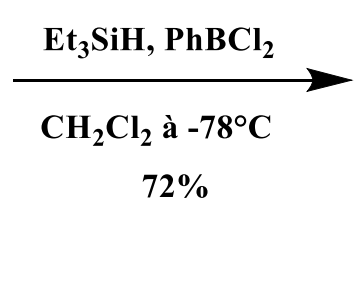

Scheme 3.

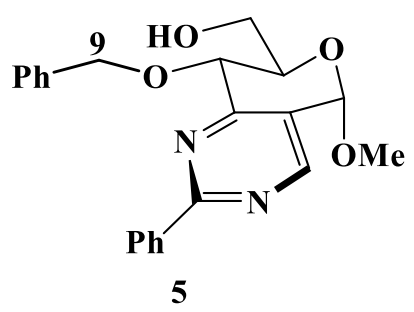

5
The use of $\mathrm{BF}_{3}$ and $\mathrm{PhBCl}_{2}$ in the reduction of compound $\mathbf{2}$ yields compounds of different regioselectivity. Steric factors can explain this fact. When a small reducing agent $\left(\mathrm{BF}_{3}\right)$ is used, the $4-\mathrm{OH} / 6-\mathrm{OCH}_{2} \mathrm{Ph}$ compound is favored, while the $6-\mathrm{OH} / 4-\mathrm{OCH}_{2} \mathrm{Ph}$ compound is preferred when a greater steric reducing agent $\left(\mathrm{PhBCl}_{2}\right)$ is used. Several authors report these observations ${ }^{10-14}$.

\subsection{Acylation reaction tests on compounds 3, 4 and 5}

An acetylation reaction of free hydroxyl allowed confirmation of the structure of compounds 3 and 6 by the variation of the chemical shift of $\mathrm{H}_{4}$ due to the formation of an ester function.<smiles>COc1cnc(S(C)(=O)=O)nc1C1COCC(O)C1O</smiles>

3

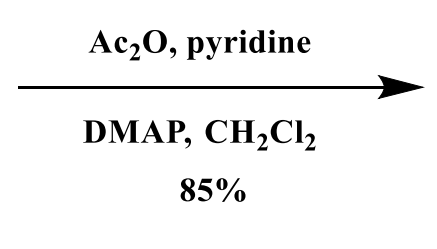

Scheme 4.

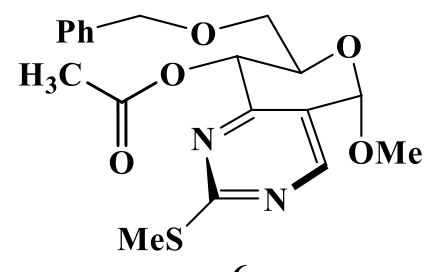

6
The confirmation of the structure of compounds 4 and
5 was performed after acetylation of free hydroxyl, Schemes 4 and 5. 
<smiles>COc1cnc(-c2ccccc2)nc1C(O)COc1ccccc1</smiles>

4<smiles>COc1c2nc(-c3ccccc3)nc1C(CO)C(CO)OC2CO</smiles>

5
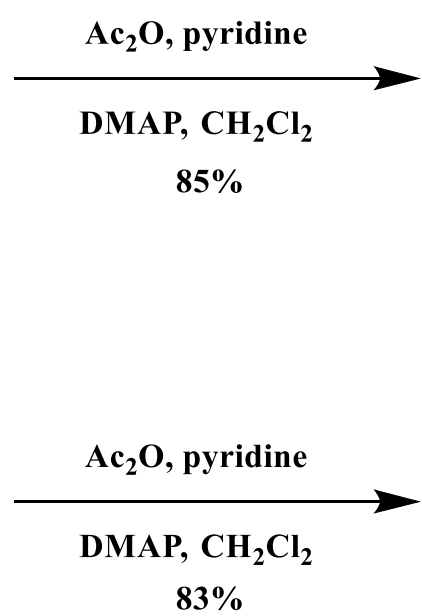

$83 \%$<smiles>COc1c2nc(-c3ccccc3)nc1C(COCc1ccccc1)OC2C</smiles><smiles>COc1c2nc(-c3ccccc3)nc1C(COC(C)=O)OC2COCc1ccccc1</smiles>

8

Scheme 5.

The variations of the chemical shifts of the $\mathrm{H} 4$ proton in the ester compound 7 and the H6 proton in the ester compound 8, comparatively to those of their respective precursors 4 and 5 are indicative of the regioselectivity of the reaction. The esterification reaction occurs on 4-OH for compound 4, while it occurs on 6-OH for compound 5. Additionally, the chemical shifts of proton $\mathrm{H} 6$ (for 4 and 7) and $\mathrm{H} 4$ (for 5 and 8 ) remain in the same region, reinforcing this observation.

\section{Conclusion}

Exploring the reactivity of the pyranose part of the pyrimidino-pyranoside platform by regioselective reduction reactions of benzylidene has been fruitful and has made it possible to develop a functionalization. Thus, this platform presents anchor points whose reactivity we control and allows the introduction of molecular diversity.

Therefore, this platform is quite interesting to develop and should allow peptidomimetics to mimic short peptide sequences.

\section{Experimental}

\subsection{Opening procedure}

Compound 3: $\quad(5 \mathrm{~S}, 7 \mathrm{R}, 8 \mathrm{~S})-2-$-Methylsylfanyl-5,8dihydro-7-benzyloxymethyl-5-methoxy-pyrano[3,4-

e]pyrimidin-8-ol.

Compound $1(100 \mathrm{mg}, 0.28 \mathrm{mmol})$ is dissolved in 5 $\mathrm{mL}$ of anhydrous dichloromethane at $-78^{\circ} \mathrm{C}$ under an argon atmosphere, then $0.13 \mathrm{~mL}$ of $\mathrm{Et}_{3} \mathrm{SiH}$ (3 eq.) and $0.1 \mathrm{ml}$ of $\mathrm{BF}_{3} . \mathrm{Et}_{2} \mathrm{O}$ (3 eq.). The reaction followed by TLC is complete after 30 min of stirring at $-78^{\circ} \mathrm{C}$. The reaction mixture is diluted with $20 \mathrm{~mL}$ of dichloromethane, washed with $10 \mathrm{~mL}$ of saturated $\mathrm{NaHCO}_{3}$ solution, and then washed with water. The organic phase is dried over magnesium sulfate and then concentrated in vacuo. The crude is purified by chromatography on a silica column (hexane / EtOAc, 3: 1). Compound 3 is isolated with a yield of $47 \%$.

${ }^{1} \mathbf{H}$ RMN ( $\left.\mathbf{C D C l}_{3}, \mathbf{2 5 0} \mathbf{M H z}\right): \delta 2.58$ (s, 3H, SMe), 3.57 (s, 3H, OMe), 3.85-4.00 (m, 2H, $\left.\mathrm{H}_{6}, \mathrm{H}_{6}{ }^{\prime}\right), 4.09$ (ddd, $1 \mathrm{H}, \mathrm{H}_{5}, J_{4-5}=9.6 \mathrm{~Hz}, J_{5-6}=4.4 \mathrm{~Hz}, J_{5-6}=2.5$ $\mathrm{Hz}), 4.66\left(\mathrm{~d}, 1 \mathrm{H}, \mathrm{H}_{9}, J_{\text {gem }}=12.5 \mathrm{~Hz}\right), 4.67\left(\mathrm{~d}, 1 \mathrm{H}, \mathrm{H}_{4}\right.$, $\left.J_{4-5}=9.6 \mathrm{~Hz}\right), 4.72\left(\mathrm{~d}, 1 \mathrm{H}, \mathrm{H}_{9}, J_{\text {gem }}=12.5 \mathrm{~Hz}\right), 5.59$ $\left(\mathrm{s}, 1 \mathrm{H}, \mathrm{H}_{1}\right), 7.25-7.40(\mathrm{~m}, 5 \mathrm{H}, H$ aromatic $), 8.40$ (s, $\left.1 \mathrm{H}, \mathrm{H}_{7}\right)$.

${ }^{13} \mathbf{C}$ RMN (CDCl 3 , 62.9 MHz) : $\delta 14.5$ (SMe), 56.1 $(\mathrm{OMe}), 65.4\left(\mathrm{C}_{9}\right), 69.2\left(\mathrm{C}_{5}\right), 70.4\left(\mathrm{C}_{6}\right), 73.8\left(\mathrm{C}_{4}\right), 96.3$ $\left(\mathrm{C}_{1}\right), 121.7\left(\mathrm{C}_{2}\right), 127.8$ (2C aromatic), 128.6 (3C aromatic), $138.3(\mathrm{Cq}$ aromatic $), 156.1\left(\mathrm{C}_{7}\right), 164.9$ $\left(\mathrm{C}_{3}\right), 173.2\left(\mathrm{C}_{8}\right)$.

HRMS $\left(\mathbf{E S I}^{+}\right)$: 371.1024 (calculated for $\left.\mathrm{C}_{17} \mathrm{H}_{20} \mathrm{~N}_{2} \mathrm{NaO}_{4} \mathrm{~S}: 371.1036\right)$.

Compound 4: (5S,7R,8S)-2-Phenyl-5,8-dihydro-7benzyloxymethyl-5-methoxy-pyrano[3,4-e] pyrimidin-8-ol.

Compound 2 ( $150 \mathrm{mg}, 0.4 \mathrm{mmol}$ ) is dissolved in $5 \mathrm{~mL}$ of anhydrous dichloromethane at $0^{\circ} \mathrm{C}$ under an argon atmosphere, $23 \mathrm{mg}$ of $\mathrm{LiAlH}_{4}$ (1.5 eq.) are then added at $0^{\circ} \mathrm{C}$. The reaction mixture is carried to reflux, and $80 \mathrm{mg}$ of $\mathrm{AlCl}_{3}$ (1.5 eq.) are added. The reaction followed by TLC is complete after 2 hours of stirring at reflux. The mixture is hydrolyzed and then extracted with dichloromethane and washed with water. The organic phase is dried over magnesium sulfate and concentrated in vacuo. Compound 4 is obtained with a yield of $65 \%$ after purification by chromatography on silica gel (Hexane / EtOAc, 1: 2).

${ }^{1} \mathbf{H}$ RMN (CDCl 3,250 MHz) : $\delta 3.62(\mathrm{~s}, 3 \mathrm{H}, \mathrm{OMe})$, $3.82\left(\mathrm{~s}, 1 \mathrm{H}, \mathrm{OH}_{4}\right), 3.90-4.00\left(\mathrm{~m}, 2 \mathrm{H}, \mathrm{H}_{6}, \mathrm{H}_{6}\right), 4.16$ (ddd, $1 \mathrm{H}, \mathrm{H}_{5}, J_{4-5}=9.8 \mathrm{~Hz}, J_{5-6}=4.8 \mathrm{~Hz}, J_{5-6},=2.6$ $\mathrm{Hz}), 4.70\left(\mathrm{~d}, 1 \mathrm{H}, \mathrm{H}_{9}, J_{\mathrm{gem}}=12.4 \mathrm{~Hz}\right), 4.75\left(\mathrm{~d}, 1 \mathrm{H}, \mathrm{H}_{9}\right.$, $\left.J_{\mathrm{gem}}=12.4 \mathrm{~Hz}\right), 4.77\left(\mathrm{~d}, 1 \mathrm{H}, \mathrm{H}_{4}, J_{4-5}=9.8 \mathrm{~Hz}\right), 5.69$ $\left(\mathrm{s}, 1 \mathrm{H}, \mathrm{H}_{1}\right), 7.30-7.45$ (m, 5H, $H$ aromatic), 7.40-7.50 
(m, 2H, $H$ aromatic), 8.45-8.55 (m, 3H, $H$ aromatic), $8.69\left(\mathrm{~s}, 1 \mathrm{H}, \mathrm{H}_{7}\right)$.

${ }^{13} \mathbf{C}$ RMN (CDCl $\left.3,62.9 \mathrm{MHz}\right): \quad \delta 56.2(\mathrm{OMe})$, $65.5\left(\mathrm{C}_{9}\right), 69.3\left(\mathrm{C}_{5}\right), 70.7\left(\mathrm{C}_{6}\right), 73.8\left(\mathrm{C}_{4}\right), 96.3\left(\mathrm{C}_{1}\right)$, $124.2\left(\mathrm{C}_{2}\right), 127.8$ (2C aromatic), 128.6 (4C aromatic), 128.8 (3C aromatic), 131.4, (C aromatic), $136.9 \quad(\mathrm{Cq}$ aromatic), 138.3 (Cq aromatic), $156.3\left(\mathrm{C}_{7}\right), 164.6\left(\mathrm{C}_{3}\right), 164.7\left(\mathrm{C}_{8}\right)$.

Compound 5: (5S,7R,8S)-2-Phenyl-5,8-dihydro-8benzyloxy-7-hydroxymethyl-5-methoxy-pyrano[3,4e] pyrimidine.

Compound 2 (200 mg, $0.5 \mathrm{mmol}$ ) is dissolved in $5 \mathrm{~mL}$ of anhydrous dichloromethane at $-78^{\circ} \mathrm{C}$ under an argon atmosphere. Next, $0.25 \mathrm{~mL}_{\text {of }} \mathrm{Et}_{3} \mathrm{SiH}$ (3 eq.) and $0.2 \mathrm{~mL}$ of $\mathrm{PhBCl}_{2}$ (3 eq.) are added. The reaction followed by TLC is complete after 45 minutes of stirring at $-78^{\circ} \mathrm{C}$. It was hydrolyzed with saturated $\mathrm{NaHCO}_{3}$ solution; the reaction mixture was extracted with dichloromethane $(20 \mathrm{ml})$ and washed with water. The organic phase is dried over magnesium sulfate and then concentrated in vacuo. The crude is purified by chromatography on a silica column (Hexane / EtOAc, 1: 1), compound 5 is thus isolated with a $72 \%$ yield.

${ }^{1} \mathbf{H}$ RMN (CDCl 3,250 MHz) : $\delta 3.58$ (s, 3H, OMe), $3.86-4.00\left(\mathrm{~m}, 2 \mathrm{H}, \mathrm{H}_{9}\right), 4.10-4.25\left(\mathrm{~m}, 1 \mathrm{H}, \mathrm{H}_{5}\right), 4.35-$ $4.45\left(\mathrm{~m}, 1 \mathrm{H}, \mathrm{H}_{6}\right), 4.60-4.75\left(\mathrm{~m}, 1 \mathrm{H}, \mathrm{H}_{6}\right), 5.10(\mathrm{~d}, 1 \mathrm{H}$, $\left.\mathrm{H}_{4}, J_{4-5}=11 \mathrm{~Hz}\right), 5.50-5.65\left(\mathrm{~m}, 2 \mathrm{H}, \mathrm{H}_{1}, \mathrm{OH}_{6}\right), 7.30-$ $7.55(\mathrm{~m}, 6 \mathrm{H}, H$ aromatic), 7.70-7.85 (m, $1 \mathrm{H}$, $H$ aromatic), 8.20-8.30 (m, $1 \mathrm{H}, H$ aromatic), 8.40$8.50(\mathrm{~m}, 2 \mathrm{H}, H$ aromatic $), 8.66\left(\mathrm{~s}, 1 \mathrm{H}, \mathrm{H}_{7}\right)$.

${ }^{13} \mathbf{C ~ R M N}\left(\mathrm{CDCl}_{3}, 62.9 \mathrm{MHz}\right): \delta 56.2(\mathrm{OMe}), 62.3$ $\left(\mathrm{C}_{9}\right), 70.3\left(\mathrm{C}_{5}\right), 71.5\left(\mathrm{C}_{6}\right), 75.5\left(\mathrm{C}_{4}\right), 96.5\left(\mathrm{C}_{1}\right), 124.9$ $\left(\mathrm{C}_{2}\right), 128.2$ (C aromatic), 128.3 (C aromatic), 128.6 (2C aromatic), 128.8 (4C aromatic), 131.2, (2C aromatic), 133.9 (Cq aromatic), 135.8 (Cq aromatic), $156.2\left(\mathrm{C}_{7}\right), 164.8\left(\mathrm{C}_{3}\right), 165.3\left(\mathrm{C}_{8}\right)$.

\subsubsection{Acetylation procedure 6,7 and 8}

Compound 3 (or 4 or 5) dissolved in $5 \mathrm{~mL}$ of dichloromethane at $0^{\circ} \mathrm{C}$, pyridine (2 eq.), acetic anhydride (2 eq.), and a spatula tip of DMAP are added. The mixture is stirred at room temperature for 30 minutes, then hydrolyzed with water. The mixture is extracted with dichloromethane, and the organic phase is dried over magnesium sulfate and then concentrated in vacuo.

Compound 6: (5S,7R,8S)-7-((benzyloxy)méthyl)-5methoxy-2-(methylthio)-7,8-dihydro-5H-pyrano[4,3d] pyrimidin-8-yl acetate.

RMN ${ }^{1} \mathbf{H}\left(\mathbf{C D C l}_{3}, 250 \mathrm{MHz}\right): \delta 2.12\left(\mathrm{~s}, \mathrm{CH}_{3} \mathrm{CO}\right)$, 2.49 (s, 3H, SMe), 3.68 (s, 3H, OMe), 3.65-3.75 (m, $\left.2 \mathrm{H}, \mathrm{H}_{6}, \mathrm{H}_{6}\right), 4.25-4.35\left(\mathrm{~m}, 1 \mathrm{H}, \mathrm{H}_{5}\right), 4.56\left(\mathrm{~d}, 1 \mathrm{H}, \mathrm{H}_{9}\right.$, $\left.J_{\text {gem }}=12 \mathrm{~Hz}\right), 4.71\left(\mathrm{~d}, 1 \mathrm{H}, \mathrm{H}_{9}, J_{\mathrm{gem}}=12 \mathrm{~Hz}\right), 5.59(\mathrm{~s}$, $\left.1 \mathrm{H}, \mathrm{H}_{1}\right), 6.07\left(\mathrm{~d}, 1 \mathrm{H}, \mathrm{H}_{4}, J_{4-5}=10 \mathrm{~Hz}\right), 7.25-7.40(\mathrm{~m}$, $5 \mathrm{H}, \mathrm{H}$ aromatic), $8.38\left(\mathrm{~s}, 1 \mathrm{H}, \mathrm{H}_{7}\right)$.
Compound 7: (5R,7S,8R)-7-((benzyloxy)methyl)-5methoxy-2-phenyl-7,8-dihydro-5H-pyrano[4,3-d] pyrimidin-8-yl acetate.

${ }^{1} \mathbf{H}$ RMN (CDCl, 250 MHz) : $\delta 2.07\left(\mathrm{CH}_{3} \mathrm{CO}\right), 3.62$ (s, 3H, OMe ), 3.75-3.82 (m, 2H, $\mathrm{H}_{6}, \mathrm{H}_{6}$ ) , 4.35-4.45 $\left(\mathrm{m}, 1 \mathrm{H}, \mathrm{H}_{5}\right), 4.59\left(\mathrm{~d}, 1 \mathrm{H}, \mathrm{H}_{9}, J_{\text {gem }}=12 \mathrm{~Hz}\right), 4.73(\mathrm{~d}$, $\left.\mathrm{H}, \mathrm{H}_{9}, J_{\text {gem }}=12 \mathrm{~Hz}\right), 5.68\left(\mathrm{~s}, 1 \mathrm{H}, \mathrm{H}_{1}\right), 6.19\left(\mathrm{~d}, 1 \mathrm{H}, \mathrm{H}_{4}\right.$, $\left.J_{4-5}=10 \mathrm{~Hz}\right), 7.35-7.55(\mathrm{~m}, 8 \mathrm{H}, H$ aromatic), 8.38$8.45\left(\mathrm{~m}, 2 \mathrm{H}, H\right.$ aromatic), $8.67\left(\mathrm{~s}, 1 \mathrm{H}, \mathrm{H}_{7}\right)$.

Compound 8: $\quad((5 \mathrm{R}, 7 \mathrm{~S}, 8 \mathrm{R})-8$-(benzyloxy)-5methoxy-2-phenyl-7,8-dihydro-5H-pyrano[4,3-d] pyrimidin-7-yl) methyl acetate.

${ }^{1} \mathbf{H} \mathbf{R M N}\left(\mathbf{C D C l}_{3}, 400 \mathrm{MHz}\right): \delta 2.07\left(\mathrm{CH}_{3} \mathrm{CO}\right), 3.59$ (s, 3H, OMe ), 4.35-4.40 (m, 1H, Hs), 4.43 (s, 2H, H9), $4.61\left(\mathrm{~d}, 1 \mathrm{H}, \mathrm{H}_{4}, J_{4-5}=9.9 \mathrm{~Hz}\right), 5.15\left(\mathrm{~d}, 1 \mathrm{H}, \mathrm{H}_{6}, J_{6-6}\right.$, $=$ $11 \mathrm{~Hz}), 5.54\left(\mathrm{~d}, 1 \mathrm{H}, \mathrm{H}_{6}, J_{6-6^{\prime}}=11 \mathrm{~Hz}\right), 5.60\left(\mathrm{~s}, \mathrm{H}, \mathrm{H}_{1}\right)$, 7.30-7.55 (m, 7H, $H$, aromatic), 8.10-8.15 (m, $1 \mathrm{H}, H$, aromatic), 8.45-8.55 (m, $2 \mathrm{H}, H$ aromatic), 8.65 (s, $\left.1 \mathrm{H}, \mathrm{H}_{7}\right)$

\section{References}

1. R. Hirschmann, K.C. Nicolaou, S. Pietranico, J. Salvino, E.M. Leahy, P.A. Sprengeler, G. Furst, A.B. Smith III, Nonpeptidal peptidomimetics with .beta.-D-glucose scaffolding. A partial somatostatin agonist bearing a close structural relationship to a potent, selective substance P antagonist, J. Am. Chem. Soc., 1992, 114, 9217-9218.

2. N. Moitessier, S. Dufour, F. Chrétien, J.P. Thiery, B. Maigret, Y. Chapleur, Design, synthesis and preliminary biological evaluation of a focused combinatorial library of stereodiverse carbohydrate-scaffold-based peptidomimetics, Bioorg. Med. Chem., 2001, 9, 511-523.

3. N. Moitessier, C. Henry, B. Maigret, Y. Chapleur, Combining pharmacophore search, automated docking, and molecular dynamics simulations as a novel strategy for flexible docking. Proof of concept: docking of arginineglycine- aspartic acid-like compounds into the avß3 binding site, J. Med. Chem., 2004, 47, 4178-4187.

4. C. Henry, N. Moitessier, Y. Chapleur, Vitronectin receptor alpha (V) beta (3) integrin antagonists: chemical and structural requirements for activity and selectivity, Mini Rev. Med. Chem., 2002, 2, 531-542.

5. S. K. Bozhena,V.M. Orekhova, E.T. Yury, N.E. Nifantiev, Is an acyl group at O-3 in glucosyl donors able to control $\alpha$-stereoselectivity of glycosylation? The role of conformational mobility and the protecting group at O-6, Carbohydrate Research, 2014, 384, 70-86.

6. Erika Mező, Mihály Herczeg, Fruzsina Demeter, Ilona Bereczki, Magdolna Csávás, Anikó Borbás. J. Org. Chem. 2021, 86, 18, 12973-12987. 
7. T. Madhubabu, S.K. Yousuf, S. Aravinda, B. Singh, D. Mukherjee, Cyanuric chloride/sodium borohydride: a new reagent combination for reductive opening of 4, 6benzylidene acetals of carbohydrates to primary alcohol, Carbohydrate Research, 2013, 381, 142-145.

8. A. Mitra, B. Mukhopadhyay, Linear synthesis of the hexasaccharide related to the repeating unit of the O-antigen from Shigella flexneri serotype 1d (I: 7, 8), Carbohydrate Research, 2016, 426, 1-8.

9. A. Aravind, S. Baskaran, 1, 3: 4, 6-Di-Obenzylidene-d-mannitol as a source for novel chiral intermediates through regioselective reductive cleavage, Tetrahedron Letters, 2005, 46, 743-745.
10. S. Ed. Hanessian, Marcel Dekker, Inc.: New York, 1997, 53-67.

11. T.V. Wang, A.V. Demchenko, Synthesis of carbohydrate building blocks via regioselective uniform protection/deprotection strategies, Org. Biomol. Chem., 2019, 17, 4934-4950.

12. J. Janssens, M.D.P. Risseeuw, J. Van der Eycken, $\mathrm{S}$. Van Calen-bergh, Regioselective ring opening of 1,3-dioxane-type acetals in carbohydrates, Eur. J. Org. Chem., 2018, 46, 6405-6431.

13. Victoria Dimakos and Mark S. Taylor. Chem. Rev. 2018, 118, 11457-11517.

14. I. Samb, N.P. Moïse, S.L. langle, Y. Chapleur, Efficient functionalizations of a pyranosidopyrimidine scaffold, Tetrahedron, 2009, 65, 896-902. 